\title{
Contractures-ectodermal dysplasia-cleft lip/palate syndrome
}

INSERM

\section{Source}

INSERM. (1999). Orphanet: an online rare disease and orphan drug data base. Contractures-ectodermal dysplasia-cleft lip/palate syndrome. ORPHA:1484

Contractures - ectodermal dysplasia - cleft lip/palate is an ectodermal dyplasia syndrome characterized by severe arthrogryposis, multiple ectodermal dysplasia features, cleft lip/palate, facial dysmorphism, growth deficiency and a moderate delay of psychomotor development. Ectodermal dysplasia manifestations include sparse, brittle and hypopigmented hair, xerosis, multiple nevi, small conical shaped teeth and hypodontia, and facial dysmorphism with blepharophimosis, deep-set eyes and microg nathia. 